Chen. P. (2012). Field experiences in instructional design and technology: Legitimate participation and stolen knowledge. Journal of Educational Technology Development and Exchange, 5(1), 13-28.

\title{
Field Experiences in Instructional Design and Technology: Legitimate Participation and Stolen Knowledge
}

\author{
Pearl Chen \\ California State University, Los Angeles
}

\begin{abstract}
This paper focuses on preparing effective instructional design and technology professionals through field experiences. A graduate-level internship seminar combining academic learning and onsite experience of working as an instructional technologist was analyzed through the lens of situated learning theory. Using a convergent mixed-methods analysis, this study examined the nature of learning that takes place in authentic practice and how learning is shaped by immersing in real-world instructional technology settings. The findings of this study suggest that legitimate participation in lived practice is conducive to active learning and engagement; moving from peripheral to central poses a special challenge for students in their role as an intern; apprentice-like learning situations may not be productive without requisite modeling and coaching; and learning from complex enculturating environments requires a good balance between experiential and reflective learning. Finally, the negative aspects of learning in a community of practice are discussed along with suggestions for future research.
\end{abstract}

Keywords: situated learning, field experience, instructional design, instructional technology, career development

Contemporary social constructivist theories based on situated learning, community of practice, and cognitive apprenticeship, suggest learning as demand driven, identify formation, and a social act within a rich cultural and social context (Brown \& Duguid, 2000; Hung; 2001). Increasingly, faculty members teaching in the instructional technology field are finding ways to incorporate these perspectives into authentic learning activities, so as to prepare future instructional technology leaders who are grounded in both theory and practice (Chen, 2006; Chen \& Javeri, 2005).
Field experiences such as internships enable students to participate in authentic practice, and thus, prepare them to learn the "tricks of the trade" (Berryman, 1991). In this study, the researcher analyzed a graduate-level instructional technology internship seminar, which combines academic learning and onsite experience of working as an instructional technologist. To understand how students' learning is shaped by immersing in real-world instructional technology settings, the researcher analyzed the course through the theoretical lens of situated learning perspective. 


\section{Defining the Field}

A broad definition of the instructional technology field has been developed by Reiser and Dempsey (2012), and the new name proposed by them, Instructional Design and Technology (IDT), is becoming more popular as the field merges the domains of instructional design and educational technology. The IDT field is defined by Resier and Dempsey as follows:

The field of instructional design and technology (also known as instructional technology) encompasses the analysis of learning and performance problems, and the design, development, implementation, evaluation and management of instructional and non-instructional processes and resources intended to improve learning and performance in a variety of settings, particularly educational institutions and the workplace (p. 5).

This definition reflects a diverse field that encompasses various knowledge domains (e.g., management, design, utilization, development, and evaluation as previously identified by Seels and Richey in 1994) and a wide range of competencies and skill sets such as those developed by the International Board of Standards for Training Performance and Instruction (see http://www.ibstpi.org for performance standards in related areas of instruction, instructional design, training management, program evaluation, and online learning).

The broad scope of the field presents a challenge not only for students (newcomers) to acquire a comprehensive understanding of the field, but also for experienced practitioners to describe the exact nature and boundaries of the field. Moreover, "the field is constantly changing. New ideas and innovations affect the practices of individuals in the field, changing, often broadening, the scope of their work" (Reiser \& Dempsey, 2012, p. 1). In this constantly evolving field, the question of how to better prepare future professionals who are grounded in both theoretical and practical aspects of the field needs to be addressed.

\section{Situated Learning Theory}

Proponents of situated learning theory maintain that a great deal of the actual practice of a profession is implicit in practice itself, and hence, the classroom environment is "deliberately designed to de-skill" (Brown \& Duguid 1996, p. 54). They do not agree with the separation between "knowing" and "doing" by suggesting that learning should be situated in the context where the knowledge is applied. They regard knowledge as a product of the activity and context in which it is produced: if the goal of learning is to gain useable, robust knowledge (Brown, Collins, \& Duguid, 1989; Brown \& Duguid, 1996). Learning that occurs in authentic context and the resulting "trajectories" are described as a process of "enculturation," in which the learners are like apprentices learning to use knowledge as tools as they develop an understanding of the rules and culture rooted in the community of practice.

Brown and Duguid (1996) use the term "stolen knowledge" to describe the nature of learning that takes place in an authentic practice. As they put it, "A great deal [of the actual practice] remains inevitably implicit in practice itself, where it is always available, for those who have access, to be stolen as required" (p. 50). They believe that learners have the natural ability to "steal" knowledge (especially implicit knowledge) from the rich context of an authentic sociocultural practice. Hence, a fundamental challenge for education is to create the learning environment "so that newcomers can legitimately and peripherally 
participate in authentic social practice in rich and productive ways - to, in short, make it possible for learners to 'steal' the knowledge they need" (p. 49).

The idea of learning as "stolen knowledge" is related to Lave and Wenger' s (1991) notion of "legitimate peripheral participation" (LPP). Lave and Wenger note that LPP is simply a way to understand learning and should not be referred to as a pedagogical strategy. It describes a process where "newcomers" become "old-timers" as they move from peripheral participation toward full participation in the sociocultural practices of a community. According to Brown and Guguid (1996), LLP has two important implications for the design of learning environments: (1) we should engage and support students in on-demand learning, and (2) we should provide ways for learners to make connections to "the world of fullblooded practice" (p. 55). Establishing those connections enables learning in the realm of LPP as "legitimate theft."

\subsection{Situated Learning Environments}

From the situated learning perspective, authentic activities are more than classroombased activities that have some sort of realworld relevance. To Brown and Guguid (1996), authentic activities are simply the ordinary practices of the culture, which usually involve collaboration, interaction, and social construction of knowledge. This perspective suggests that social interaction and collaboration inherent in authentic practices are crucial to the theory of situated learning.

Taken together, situated learning theory regards knowledge as lived practices and learning as increasing participation in communities of practice (Driscoll, 2000). It emphasizes knowledge as cultural tools, learning as enculturation, legitimate peripheral participation, learning as active appropriation (of the knowledge, beliefs, and behaviors of the culture in which the knowledge is used), collaboration, and social construction of knowledge. Herrington and Oliver's (2000) elements and guidelines for designing situated learning environments provide a useful framework through which to analyze the situated nature of learning (see Table 1 ).

\section{Field Experiences in IDT}

It is common for graduate programs in IDT to offer professional internship courses to help students make connections between theory and practice. Brown (2009), for example, reviewed fourteen IDT graduate program websites and found many similarities in internship requirements across the programs. However, research on this important component of students' training in the IDT field is scarce. In her review of the literature on professional internships across a variety of disciplines, Brown found that successful internships must provide opportunities for students to make connections between theory and practice, as well as to articulate how their knowledge base has evolved. Moreover, carefully designed internship components, strong mentoring by both onsite and universities supervisors, and forming a community of practice of an internship cohort are elements found to be critical to an effective internship program.

Due to the lack of research on this topic, little is known about how students' learning is influenced by immersing in an authentic IDT practice. Is placing students in reallife settings sufficient to help them make connections to the actual practice? Is it effective in helping them make connections between theory and practice? What is the nature of students' learning and engagement in the field? How might their professional 
Table 1. Elements and Guidelines for Situated Learning (Herrington \& Oliver, 2000)

\begin{tabular}{|c|c|}
\hline Element & Guidelines \\
\hline Provide authentic contexts & $\begin{array}{l}\text { reflect real use of knowledge; preserve the complexity of the } \\
\text { real-life setting with rich situational affordances; a large number } \\
\text { of resources }\end{array}$ \\
\hline $\begin{array}{l}\text { Provide authentic } \\
\text { activities }\end{array}$ & $\begin{array}{l}\text { ill-defined activities which have real-world relevance; } \\
\text { opportunity for students to define the tasks, detect relevant } \\
\text { information, and collaborate; a sustained period of time for } \\
\text { investigation }\end{array}$ \\
\hline $\begin{array}{l}\text { Provide access to expert } \\
\text { performances and } \\
\text { modeling }\end{array}$ & $\begin{array}{l}\text { access to the social periphery, expert thinking and modeling, and } \\
\text { learners in various levels of expertise; sharing of stories }\end{array}$ \\
\hline $\begin{array}{l}\text { Provide multiple roles and } \\
\text { perspectives }\end{array}$ & $\begin{array}{l}\text { different perspectives on the topics from various points of view; } \\
\text { opportunity to express different points of view }\end{array}$ \\
\hline $\begin{array}{l}\text { Support collaborative } \\
\text { construction of knowledge }\end{array}$ & $\begin{array}{l}\text { emphasize group tasks, collaborative learning in pairs or small } \\
\text { groups, and whole group achievement }\end{array}$ \\
\hline Promote reflection & $\begin{array}{l}\text { nonlinear learning and reflection; opportunity for learners to } \\
\text { compare with experts and other learners; collaborative groupings } \\
\text { of students }\end{array}$ \\
\hline Promote articulation & $\begin{array}{l}\text { complex task incorporating inherent opportunities to articulate; } \\
\text { groups to enable articulation; public presentation }\end{array}$ \\
\hline $\begin{array}{l}\text { Provide coaching and } \\
\text { scaffolding }\end{array}$ & $\begin{array}{l}\text { guidelines for different contexts; peer learning and coaching; } \\
\text { teacher coaching and scaffolding }\end{array}$ \\
\hline $\begin{array}{l}\text { Provide for authentic } \\
\text { assessment of learning } \\
\text { within the tasks }\end{array}$ & $\begin{array}{l}\text { opportunity for students to craft polished performances or } \\
\text { products; significant student time and effort in collaboration; } \\
\text { complex, ill structured challenges that require judgment, and a } \\
\text { full array of tasks; assessment to be seamlessly integrated with } \\
\text { the activity; multiple indicators of learning and appropriate } \\
\text { criteria for scoring varied products }\end{array}$ \\
\hline
\end{tabular}

identity be shaped by the process of enculturation? Are there commonalities and/or differences in students' learning trajectories? This study was the first of a series of studies devoted to understand IDT field experiences through the theoretical lens of situated learning perspective. The purpose in this first step was to gain a better understanding of students' field experiences in relation to the critical elements of situated learning. This study was guided by the following three research questions:

1. What are students' perceptions of the value and quality of their IDT internship experience? 
2. What is the nature of students' learning and engagement situating in a lived IDT practice?

3. What are the positive aspects (affordances) and negative aspects (constraints) of learning as a "legitimate peripheral participant" in a lived IDT practice?

\section{Methods}

\subsection{Instructional Context}

This study was conducted in a state university located in the heart of metropolitan Los Angeles. Participants included 44 students enrolled in three different internship seminars during Spring Quarter 2011, Winter Quarter 2012, and Spring Quarter 2012 . The internship seminar was a required course taken at the end of the students' master's program in IDT. It is designed to involve students in real-world experiences where they can apply what they have learned from previous courses, and gain a first-hand look at the role and responsibilities of working as an instructional technologist. It encourages students to identify and discuss real-world issues in IDT as they participate in creative problem solving and reflection with a cohort of interns.

Students were responsible for completion of 60 hours of internship along with course assignments designed to enhance their field experience: Internship Journal, Case Study Analysis, Internship Presentation, and Internship Write-up. To assist students and site supervisors in planning for meaningful projects and activities, various forms were created and available for download from the course site. In particular, a detailed Project Plan including milestones, responsibilities, and due dates was required to be completed by the students, agreed and signed by the site supervisor, and then returned to the faculty supervisor prior to the start of the internship.
Students also kept a detailed Time Log throughout the internship experience. Site supervisors were responsible for evaluating intern performance by completing a Mid-Term Evaluation Form and a Final Evaluation Form. Students also had a chance to evaluate their own performance by completing a mid-term and a final evaluation.

An extensive list of potential internship sites could be downloaded as an Excel file from the course site. Students could choose up to three sites or recommend a site, and then the faculty supervisor helped them finalize a site placement based on their written professional growth plans. Additional supporting materials included a list of FAQs, a Protocol for Contacting Sites, a Student Manual, and a Site Supervisor Manual, which was created to help onsite supervisors create meaningful projects for both the intern and the hosting organization.

The course site served as a central space for students to share their internship stories and assignments, as well as to download course instructions and rubrics. A weekly reminder of due dates and requirements was sent to the students from the course site. To encourage peer learning, the Case Study assignment based on Ertmer and Qunn's (2007) book, The ID Casebook: Case Studies in Instructional Design, required students to work with a peer partner to research, analyze, and reflect on their own internships. Due to the university's quarter schedule, the internship course was completed in eleven weeks with three required campus meetings at the beginning, middle, and end of the quarter.

\subsection{Participants}

Forty-four students (30 females and 14 males) between the ages of 23 and 54 participated in this study. There were 17 Hispanics, 14 Asian Americans, 8 Caucasians, 
3 African Americans, and 2 Bi-racial students. Seventy-two percent $(n=32)$ of the participants were employed full-time while pursuing a master's degree in IDT as full-time students. Participants were placed at different instructional technology sites as interns under the joint supervision of a university supervisor and an IDT specialist as onsite supervisor. Site placement included school district offices $(\mathrm{n}=9)$, local K-12 schools $(\mathrm{n}=9)$, universities $(n=8)$, community colleges $(n=6)$, non-profit organizations $(\mathrm{n}=5)$, technology consulting companies $(n=2)$, online learning and/or multimedia companies $(n=2)$, health care providers $(\mathrm{n}=2)$, and a broadcast television site $(n=1)$. Examples of internship activities completed by the participants included planning and conducting staff development workshops, creating instructional or training materials, developing online courses or websites, assessing technology programs, managing labs and other technology resources, developing technology policies/guidelines, participating in technology planning, grant writing, and facilitating the implementation of school/district networks for instruction.

\subsection{Data Sources and Analysis}

This study used a mixed-methods design combining qualitative and quantitative techniques. Advantages of this design include providing sufficient evidence, incorporating multiple paradigms, combining inductive and deductive thinking, adopting a practical approach using both words and numbers, and ultimately providing a more complete understanding of the research problem (Creswell \& Plano Clark, 2011). More specifically, this study used the "convergent design" strategy that involves "concurrent quantitative and qualitative data collection, separate quantitative and qualitative data analyses, and the merging of the two data sets" (Creswell \& Plano Clark, 2011, p. 73).
Multiple data sources were collected and analyzed. Qualitative data included weekly journal entries, discussion board/email messages, student assignments/artifacts, student reflections, and responses to the open-ended questions on the evaluations of internship experience. Quantitative data included student demographics and selfratings of internship performance, as well as student ratings of effectiveness of internship and quality of supervision using a 5-point Likert scale.

Data analysis involved the following procedures recommended by Creswell and Plano Clark (2011): preparing the data for analysis, exploring the data, analyzing the data, representing the data analysis, and interpreting the results. Qualitative data analysis involved coding the data based on categories from the literature (i.e., Herrington and Oliver's critical elements of situated learning) as well as codes that emerged from the data, assigning labels to codes, grouping codes into themes, and linking interrelated themes. Quantitative data analysis involved conducting a descriptive analysis of student ratings and examining the general trends of student responses. Various data sources allowed the researcher to triangulate observations and interpretations of findings. Member checking was employed in the form of conversations and clarifications between the researcher and research participants.

\section{Findings and Interpretations}

\section{Research Question\#1: What are students' perceptions of the value and quality of their IDT internship experience?}

Student comments indicated their positive perceptions regarding the quality and value of their internship experience. Thirty-six students $(82 \%)$ stated that their internship either meet or exceeded their expectations; 
two students had mix feelings about their internship, and two students reported that their internship did not meet their expectations. To check on ideas and themes developed from qualitative data, the researcher examined the responses obtained from students' evaluations of internship experience. Results suggest an overall high quality ( $5=$ Excellent $)$ in all aspects of students' internship experience. As shown in Table 2, three categories received the highest "Excellent" ratings: the intern was treated as a professional (91\%), interest shown in intern $(82 \%)$, and opportunity to develop new skills/knowledge (82\%). The three lowest "Excellent" ratings include current skills/ knowledge applied in the internship activities $(68 \%)$, availability of professional role models at site $(66 \%)$, and adequate resources were provided to the intern $(64 \%)$.

Table 2. Evaluation of Internship Experience $(\mathrm{N}=44)$

\begin{tabular}{|c|c|c|c|c|c|c|}
\hline \multirow{2}{*}{ Statement } & \multicolumn{5}{|c|}{ Percentage $(\mathrm{n})^{*}$} & \multirow{2}{*}{ Mean $(S D)$} \\
\hline & 1 & 2 & 3 & 4 & 5 & \\
\hline $\begin{array}{l}\text { - The intern was treated } \\
\text { as a professional }\end{array}$ & - & - & $2 \%(1)$ & $7 \%(3)$ & $91 \%(40)$ & $4.9(0.4)$ \\
\hline - Interest shown in intern & - & - & $5 \%(2)$ & $14 \%(6)$ & $82 \%(36)$ & $4.8(0.5)$ \\
\hline - Quality of supervision & - & $5 \%(2)$ & $2 \%(1)$ & $16 \%(7)$ & $77 \%(34)$ & $4.7(0.7)$ \\
\hline $\begin{array}{l}\text { - Clarity in the } \\
\text { description of tasks/ } \\
\text { duties }\end{array}$ & - & - & $9 \%(4)$ & $16 \%(7)$ & $75 \%(33)$ & $4.7(0.6)$ \\
\hline $\begin{array}{l}\text { - Current skills/ } \\
\text { knowledge applied in } \\
\text { the internship activities }\end{array}$ & - & - & $5 \%(2)$ & $27 \%(12)$ & $68 \%(30)$ & $4.6(0.6)$ \\
\hline $\begin{array}{l}\text { - Opportunity to develop } \\
\text { new skills/knowledge }\end{array}$ & - & - & $2 \%(1)$ & $16 \%(7)$ & $82 \%(36)$ & $4.8(0.5)$ \\
\hline $\begin{array}{l}\text { - Adequate resources } \\
\text { were provided to the } \\
\text { intern }\end{array}$ & $2 \%(1)$ & - & $9 \%(4)$ & $25 \%(11)$ & $64 \%(28)$ & $4.5(0.8)$ \\
\hline $\begin{array}{l}\text { - Availability of } \\
\text { professional role } \\
\text { models at site }\end{array}$ & $5 \%(2)$ & $2 \%(1)$ & $7 \%(3)$ & $18 \%(8)$ & $66 \%(29)$ & $4.3(1.2)$ \\
\hline
\end{tabular}

*Scale used: $1=$ Poor, $5=$ Excellent 
Qualitative findings revealed that working with experts in authentic IDT settings, real-world applications of knowledge, and opportunities to develop new skills were some of the most valuable aspects of the internship experience. Participants commented:

- This site reveals the real world of instructional designers and technologists. In my experience, I learned a great deal from this practicum.

- It is a great experience to learn new skills and apply them in the real-world setting.
- This Internship prepared me to see how students can apply theory into reallife situations through placement in an appropriate work-related setting.

- My greatest reward was having the opportunity of working with experts in the field of technology and teaching.

Students' perceptions of the value of their internship in relation to the critical elements of situated learning are shown in Table 3.

Table 3. Examples of Student Comments in Relation to the Critical Elements of Situated Learning (Herrington \& Oliver, 2000)

\begin{tabular}{|c|c|}
\hline Element & Examples of Student Comments \\
\hline $\begin{array}{l}\text { Provide authentic } \\
\text { contexts }\end{array}$ & $\begin{array}{l}\text { - Doing internships provides great experiences that you may only get in } \\
\text { the field. } \\
\text { - I received a glimpse into the "real world" of instructional designers } \\
\text { and technologists. The reality outweighed the theories, case studies, } \\
\text { and hypothetical scenarios that you read about in class. Everything } \\
\text { we read in class is important, too; but for me it didn't quite compare } \\
\text { to the reality check. }\end{array}$ \\
\hline $\begin{array}{l}\text { Provide authentic } \\
\text { activities }\end{array}$ & $\begin{array}{l}\text { - My internship provided me with real life projects that enhanced my } \\
\text { learning in instructional design and technology. } \\
\text { - I was able to see how to apply IDT skills and knowledge in the real } \\
\text { world. I learned how to build an online course and how Moodle } \\
\text { works. I also learned how to run technology workshops. }\end{array}$ \\
\hline $\begin{array}{l}\text { Provide access } \\
\text { to expert } \\
\text { performances and } \\
\text { modeling }\end{array}$ & $\begin{array}{l}\text { - My internship helped me realize all the inner workings that went into } \\
\text { being a technology coordinator. } \\
\text { - It was helpful to be exposed to their daily routines because it } \\
\text { was informative as to all the responsibilities and many hats of an } \\
\text { instructional designer. }\end{array}$ \\
\hline $\begin{array}{l}\text { Provide multiple } \\
\text { roles and } \\
\text { perspectives }\end{array}$ & $\begin{array}{l}\text { - I can now "see" the other angles that co-workers, potential learners, } \\
\text { and bosses will require of me. } \\
\text { - I learned to be open to any ideas that are presented and soak up as } \\
\text { much information from others and listen to the advice and accounts } \\
\text { they have on their own learning experiences. }\end{array}$ \\
\hline
\end{tabular}


Support

collaborative

construction of

knowledge

Promote reflection

Promote

articulation

Provide coaching and scaffolding
- Collaboration was important because I worked with my supervisor as well as a co-worker to get my projects done.

- The internship is an integral part of what we know as experiential learning. It places us in a situation where we build relationships, work collectively/collaboratively, put into practice some of the tacit knowledge we have acquired through our own learning experiences, so that we may construct the final products and desired outcomes we tend to see as moments of inspiration and sense of accomplishment.

- I realize the importance of learning new methods of doing things and being open to change.

- It made me realize I would like to use IDT for something I feel related to and passionate about.

- The journals allowed me to reflect on my practices, improve on them and relate them to the field of Instructional Design and Technology (IDT).

- If your supervisor does not have a clear vision, you can create a prototype to show them what you can do and help to see their vision.

- During our weekly meetings, my supervisor and her team shared "behind the scene" information about their daily operation.

- We were given constructive feedback about our progress and the project. Recommendations were given. Clearly the supervisor wanted us to succeed.

- It feels great to know that my internship work is going to provide teachers the opportunity to incorporate more technology in their lessons.

- My internship will help people, help themselves and in turn become better instructors or allow them to do their jobs without being held back by technology.
Research Question\#2: What is the nature of students' learning and engagement situating in a lived IDT practice?

Students reported learning multiple skills such as project/time management, planning, research, product creation, communication, instructional design, presentation, and technology skills. Authentic activities embedded in the real-world contexts are highly engaging. In their role as legitimate participants, students often go above and beyond internship requirements, as indicated by the following comments:

- I have been working on the required tasks and will continue to do so even after the 60 hours are complete.

- I did not see this as a class assignment but as a job interview. I made sure that I gave more than $100 \%$ in everything I was assigned and did more than I was assigned. 
- I will continue to work closely with my site supervisor over the summer. This will be an ongoing project I will work even after the completion of the internship class,
Three recurring themes pertaining to students' learning trajectory were identified: (1) gaining confidence, (2) broadening perspectives, and (3) going beyond boundaries (see Table 4).

Table 4. Examples of Student Comment Pertaining to the Recurring Themes of Students' Learning Trajectory.

\section{Gaining confidence}

- I feel more prepared and less lost as a future professional in the field of instructional technology.

- I feel more prepared to pursue a career as an Instructional Technology Coordinator. I have a clearer idea of how to use the skills I've developed up to this point and I know which skills I need to build.

- The internship has contributed to my future goals by giving me the confidence to believe that I can be an effective Instructional Technology Coordinator.

- I now feel more confident in my skills. I also gained respect from my co-workers as well as gained respect for myself.

- The most important thing I gained in this internship was confidence. I started out very weak in my abilities to implement and learn technology tools but now I feel I might be ready to present what I know to both my colleagues and beyond.

\section{Broadening perspectives}

- It has broadened my perspective on career opportunities in higher education, which I did not take into account before I started the internship.

- I always saw myself as a teacher. I love teaching, however, the internship allowed me to see that I can still stay in the education field, but just not as a teacher.

- I realize there are many more possibilities than remaining a teacher and using my skills in the classroom.

- I found out so much more about IDT, how really large it is...I really feel like this field is still evolving, and will continue to do so, and I want to help it grow, by learning as much as I can-especially since I know how much more there is out there!.

\section{Going beyond boundaries}

- I learned that it necessary to take risks and come out of one's comfort zone.

- I feel more motivated to develop in this field outside of the classroom. I'm going to join instructional technology associations and attend conferences in the future.

- I think that after this experience I am ready to present what I have learned and the projects that I have worked on. At the beginning of my internship my supervisor mentioned that I may be presenting at a conference to show what we have accomplished. When I heard that I shuttered and froze...now I hope to enter an education conference to present. 
Several students described the experience as "a huge paradigm shift" from where they began as a teacher to a leader and an agent of change at their school. One student commented "I learned that I can become somewhat of an expert when no expert is provided on the topic." New career opportunities were opened to some students as a result of their internship: "My colleague and I grew professionally and were both offered leadership roles in our school site." Being able to connect to the larger perspective of the actual practice, to build professional relationships, to work collaboratively with others, and to construct authentic, meaningful products provide a sense of "practicing" in the field. The experience was valuable for the students to develop their professional identity, as indicated by the following excerpt:

My internship has given me a breadth of knowledge that will benefit me as I move along the IDT trajectory... My professional goals are becoming defined as I ask my supervisor questions about the IDT field, technology, education, and about professional development beyond the internship. I think that for many of us this experience will allow us to find our niche in this vast field.

Research Question\#3: What are the positive aspects (affordances) and negative aspects (constraints) of learning as a "legitimate peripheral participant" a lived IDT practice?

The highly engaging real-world context is desirable to sustain student motivation, yet it can be an "overwhelmingly empowering experience" as described by these students: "It felt very empowering and at the same time I feel the huge weight of responsibility if plans are not successful." and "We were exposed to so many technology tools and resources, instructional resources, and online professional development that at times it felt very overwhelming."
The merging of different data sources enabled a detailed analysis of the learning environment in terms of its affordances and constraints (see Table 5 on next page).

\section{Time Constraints and Over-involvement}

Because the majority of the students were juggling between school work and a full-time job, the issue of time constraints left "bittersweet feelings" for them as "many things are still undone." For example, students commented:

- It has been extremely hard to work a fulltime teaching assignment with the classes and an internship.

- I was short on time. Other assignments, and other classes, were a constraint on how much I could invest in building the online course.

As indicated in Table 5, students often dealt with multiple tasks. They were enthusiastic and were eager to be involved in the "overall scheme of things" at their site. The problem of over-involvement was complicated by the students' lack of skills in defining the tasks and/or detecting relevant vs. irrelevant information during the initial stage of their internship. This contributed to an overwhelming feeling as suggested by the following comment:

I am too over ambitious. I mean I knew this before, but having this internship on top of everything else really hit home to me that I need to learn how to just take a break sometimes and pace myself better.

\section{Discussion}

Major themes emerged from the findings are discussed as follows: 
Table 5. Affordances and Constraints in Relation to the Elements of Situated Learning (Herrington \& Oliver, 2000)

\begin{tabular}{|c|c|}
\hline Element & Affordances (A) and Constraints (C) \\
\hline $\begin{array}{l}\text { Provide authentic } \\
\text { contexts }\end{array}$ & $\begin{array}{l}\text { A-Internship provided the complexity of rich situational } \\
\text { affordances, reflecting how knowledge is used in real-life. } \\
\text { C-Resources varied from site to site. }\end{array}$ \\
\hline $\begin{array}{l}\text { Provide authentic } \\
\text { activities }\end{array}$ & $\begin{array}{l}\text { A-A wide range of real-world, ill-defined activities } \\
\text { C-Students often dealt with multiple tasks; difficult to define } \\
\text { the tasks and/or detect relevant vs. irrelevant information; time } \\
\text { constraints did not allow sustained investigation; opportunity to } \\
\text { collaborate varied from site to site. }\end{array}$ \\
\hline $\begin{array}{l}\text { Provide access } \\
\text { to expert } \\
\text { performances and } \\
\text { modeling }\end{array}$ & $\begin{array}{l}\text { A-Access to onsite experts, faculty supervisor, and peers; sharing of } \\
\text { stories via journal entries, class discussions, and presentations. } \\
\text { C-Access to expert thinking and modeling varied from site to site }\end{array}$ \\
\hline $\begin{array}{l}\text { Provide multiple } \\
\text { roles and } \\
\text { perspectives }\end{array}$ & $\begin{array}{l}\text { A-Multiple perspectives were encouraged in class discussions and } \\
\text { assignments (e.g., Peer Reviewer). } \\
\text { C-Time. }\end{array}$ \\
\hline $\begin{array}{l}\text { Support } \\
\text { collaborative } \\
\text { construction of } \\
\text { knowledge }\end{array}$ & $\begin{array}{l}\text { A-Internship cohort as a community of practice } \\
\text { C-Opportunity to collaborate varied from site to site; expectation } \\
\text { of individual achievement created a sense of competition among } \\
\text { interns working at the same site. }\end{array}$ \\
\hline $\begin{array}{l}\text { Promote } \\
\text { reflection }\end{array}$ & $\begin{array}{l}\text { A-Opportunity for students to compare themselves with experts and } \\
\text { other interns; self-evaluations and ongoing feedback. } \\
\text { C-Limited time and group interactions. }\end{array}$ \\
\hline $\begin{array}{l}\text { Promote } \\
\text { articulation }\end{array}$ & $\begin{array}{l}\text { A-Internship requirements and course assignments incorporated } \\
\text { inherent opportunities to articulate. } \\
\text { C-Time. }\end{array}$ \\
\hline $\begin{array}{l}\text { Provide coaching } \\
\text { and scaffolding }\end{array}$ & $\begin{array}{l}\text { A-Course provided guidelines, forms, instructions, rubrics, and } \\
\text { reminders; opportunities for peer and instructor coaching. } \\
\text { C-The extent of onsite coaching and scaffolding varied from site to } \\
\text { site. }\end{array}$ \\
\hline $\begin{array}{l}\text { Provide for } \\
\text { authentic } \\
\text { assessment of } \\
\text { learning within } \\
\text { the tasks }\end{array}$ & $\begin{array}{l}\text { A-Embedded assessment in the real-life tasks completed by the } \\
\text { interns; multiple indicators for evaluation such as communication, } \\
\text { IDT knowledge and skills, and organizational effectiveness. } \\
\text { C-Time to craft polished performances or products; timely } \\
\text { submission of evaluation and feedback by site supervisors. }\end{array}$ \\
\hline
\end{tabular}




\section{Legitimate participation and active} learning. Arguably, internship embodies the most enculturating nature of learning experience for students to discover the covert aspects of the actual practice. It provides the "window' for students to "look through to as much of actual practice as it can reveal" (Brown \& Duguid, 1996, p. 55). In the current study, real-world contexts and authentic activities appeared to be highly engaging. In their role as legitimate participants, students often went beyond internship requirements and continued to work at their site after their internship. While the highly engaging context is desirable to sustain student motivation, it may also lead to over-involvement and counterproductive outcomes for some students. Hence, great care must be taken as students enter into real-world communities of practice.

Moving from peripheral to central. It was quite often the case that the students were not just involved peripherally, but participated centrally in the new initiatives undertaken by their internship sites. Being able to assume major responsibilities created both opportunities and challenges. While it led to new career opportunities for a number of students, it added a considerable amount of stress on students who were juggling a fulltime job with school work and internship responsibilities. This challenge became even greater by situational constraints such as inadequate resources, poor quality of support/ supervision, and/or a lack of clarity in the description of tasks and duties.

Cognitive apprenticeship. From the situated learning perspective, internship presents an ideal opportunity of learning through cognitive apprenticeship as students are exposed to experts in the real-world practice. Cognitive apprenticeship emphasizes scaffolding learning by making the thinking process underlying complex, problemsolving tasks visible through methods such as modeling, coaching, scaffolding, articulation, and reflection (Collins, Brown \& Newman, 1989; Collins, Brown, \& Holum, 1991). This process requires time, experience, and skills on the part of the expert to diagnose problems, provide feedback, offer encouragement, and remedy performance deficiencies.

Because most of the site supervisors are busy instructional technology practitioners, the varying extent of onsite coaching and modeling is one of the major challenges we continue to face. The incorporation of case study as a strategy for "anchored instruction" (CGTV, 1990; 1993) appeared to be useful in helping students identify expert strategies and resources relevant to their internship, as indicated by the following excerpt:

The case study I chose helped me tremendously because it presented a similar case to what I witnessed, which was the implementation of Moodle, a new learning management system software, and the negative feeling of few faculty members toward the software and its transition.

Class discussions and reflections were structured around case studies related to students' internship situations. Students found this experience "enlightening" in terms of helping them understand multiple perspectives. One student commented:

I realized that we had all focused on different parts which we individually found important. That to me was my Aha! moment, and why so many people in this field might gravitate to different sections of the field.

In addition, emphasizing intern cohort as a knowledge building community (Scardamalia \& Bereiter, 1994; 2003) appeared to foster peer learning and collective cognitive responsibility (Scardamalia, 2002). 
Learning from complex enculturating environments. The progressive process of "learning as enculturation" requires student apprentices to see through the lens of a particular practice and to construct meaning based on the norms or belief systems commonly held within that practice. Educators cannot simply place students in real-life environments and expect them to be able to deal with complex, ill-defined tasks. It is necessary to help them achieve a deeper understanding of the practice by connecting academic learning to real-life applications. Reflection, self-evaluation, and articulation of field experience both in class and online appeared to be effective in uncovering the process aspects of students' developing expertise. Further, reflective and metacognitive strategies will need to be developed to help students internalize their learning from complex sociocultural environments.

Negative aspects of learning in a community of practice. Hay (1996) cautioned about the negative aspects of learning in a community of practice, which can be "sectarian, dictatorial, controlling, divisive, exploitative, cliquish" (p. 92). Even though most of the students had a positive and productive relationship with their sites and site supervisors, a number of them found their sites to be restrictive rather than supportive for them to contribute "legitimate knowledge." Hay described this situation in terms of a "loosely formed apprenticeship" (p. 96) in which the learner is treated as a participant in a peripheral position. As a result, the tasks assigned to the students may not be meaningful to them, as described by one student:

The projects are already set in play... I simply accomplish some of the tasks needed to accomplish the project...I felt I did not want to go out of my bounds nor underperform. I felt limited.
When students are not empowered to contribute to legitimate knowledge, they may be in danger of only learning one way of doing things. On the other hand, the negative aspect of exploitation may occur when students are given an insurmountable task which they are unable to complete due to time and resource constraints. When this happened in the current study, students were overwhelmed and felt "trapped" by a sense of commitment to their sites. Hence, great care must be taken about the negative aspects of learning in a community of practice.

\section{Conclusion}

Situating future instructional technologists in a lived practice prepares the students to learn the "tricks of the trade" (Berryman, 1991). As we continue to involve our students in complex situated learning environments, supporting them with effective scaffoldings remains to be an important task for us. It is imperative that we achieve a proper balance between experiential field-based learning and reflective classroom-based learning. Through reflection, articulation, and knowledge building, students placed in different situational contexts may converge on a shared, articulated understanding (Brown \& Duguid, 1996).

The results of this study support pervious findings suggesting that carefully designed internship components, strong mentoring by supervisors, and forming a community of practice of an internship cohort are critical to an effective internship program (Brown, 2009). Moreover, opportunities for students to experience linkages between theory and practice, differences in students' skill sets and how adept they are at overcoming obstacles, as well as their work and personal lives are all influential factors affecting the success of an internship program. These initial findings offer insight into students' learning trajectory and 
how the complex, real-world activities may shape the development of their professional identity. Questions remain to be answered include: What are essential field activities in IDT? How do we facilitate the application of theoretical concepts in practical settings? What are some of the best ways to combine classroom and field learning?

This study was the first of a series of studies devoted to understand IDT field experiences through the theoretical lens of situated learning perspective. It is limited in terms of its scope. Because the study only focused on one IDT internship course, the results are not generalizable to other institutions offering similar courses such as those identified by Brown (2009). A large scale, cross-institutional analysis is needed to provide better understanding of the issues involved in preparing future instructional technologists through field experiences. Moreover, a detailed quantitative analysis is needed to investigate a wide range of situational factors and their correlations with students' learning and development in the field. The long-term impacts of field-based learning in IDT should also be addressed through future research.

\section{References}

Berryman, S. (1991). Designing effective learning environments: Cognitive Apprenticeship Models. Institute on Education and the Economy, Brief (1).

Brown, C. (2009). Elements of Successful Internships. Proceeding of the 2009 Association for Educational Communications and Technology Convention (pp. 41-49).

Brown, J. S., \& Duguid, P. (1996). Stolen Knowledge. In H, McLellan (Ed). Situated Learning Perspectives (pp. 47-56). Englewood Cliffs, NJEducational Technology Publications.
Brown, J.S., \& Duguid, P. (2000). The Social Life of Information. Cambridge, MA: Harverd Business School Press.

Brown, J.S., Collins, A., \& Duguid, P. (1989). Situated cognition and the culture of learning. Educational Researcher, 18(10), 32-43.

Chen, P., \& Javeri, M, (2005). Fortune 501: Use of cognitive apprenticeship model for a simulated instructional design course. Journal of Instruction Delivery Systems, 19(2), 12

Chen, P. (2006). Learning by building knowledge with peers. Journal of Instruction Delivery Systems, 20 (2).

Cognition \& Technology Group at Vanderbilt. (1990). Anchored instruction and its relationship to situated cognition. Educational Researcher, 19(6), 2-10.

Cognition \& Technology Group at Vanderbilt. (1993). Anchored instruction and situated cognition revisited. Educational Technology, 33(3), 52-70.

Collins, A., Brown, J. S., \& Holum, A. (1991). Cognitive Apprenticeship: Making Thinking Visible. American Educator, 15(3), 6-11, 38-46.

Creswell, J. W., \& Plano Clark, V. L. (2011). Designing and conducting mixed methods research. Thousand Oaks, CA: Sage Publications.

Driscoll, M. (2000). Psychology of learning for instruction. Needham Heights, MA: Allyn \& Bacon.

Ertmer, P. A., \& Quinn, J. (2007). The ID Casebook: Case Studies in Instructional Design, $3^{\text {nd }}$ Ed. Upper Saddle River, NJ: Pearson Education

Hay, K. E. (1996). Legitimate Peripheral Participation, Instructionism, and Constructivism: Whose Situation Is It Anyway? In H. McLellan (Ed.), Situated Learning Perspectives (pp. 89-99). Englewood Cliff, New Jersey: Educational Technology Publications. 
Herrington, J., \& Oliver, R. (2000). Critical characteristics of situated learning: Implications for the instructional design of multimedia. Retrieved from: http://www. ascilite.org.au/conferences/melbourne95/ smtu/abstracts/herrington.html

Hung, D. (2001). Design principles for Web-based learning: Implications from Vygotskian Thought. Educational Technology, 30(3), 33-40.

Lave, J., \& Wenger, E. (1991). Situated Learning-Legitimate Peripheral Participation. Cambridge: Cambridge University Press.

Reiser, R.A., \& Dempsey, J.V. (Eds.) (2012). Trends and Issues in Instructional Design and Technology (3rd ed.). Saddle River, NJ: Pearson Education.

Scardamalia, M., \& Bereiter, C. (1994). Computer support for knowledge-building communities. The Journal of the Learning Sciences, 3(3), 265-283.
Scardamalia, M. (2002). Collective cognitive responsibility for the advancement of knowledge. In B. Smith (Ed.), Liberal education in a knowledge society. (p. 76-98). Chicago,IL: Open Court.

Scardamalia, M., \& Bereiter, C. (2003). Knowledge building. In Encyclopedia of Education. (2 ${ }^{\text {nd }}$ Ed., p. 1370-1373). New York: Macmillan Reference, USA.

Seels, B. B., \& Richey, R. C. (1994). Instructional technology: The definition and domains of the field. Washington, D. C.: Association of Education Communications and Technology.

\section{Contact the Author}

\section{Pearl Chen}

California State University, Los Angeles Email: hchen6@exchange.calstatela.edu 